\title{
Immunolocalization of avian $\beta$-defensins in the hen oviduct and their changes in the uterus during eggshell formation
}

\author{
A M Abdel Mageed, N Isobe and Y Yoshimura \\ Graduate School of Biosphere Science, Hiroshima University, Higashi-Hiroshima 739-8528, Japan \\ Correspondence should be addressed to Y Yoshimura; Email: yyosimu@hiroshima-u.ac.jp
}

\begin{abstract}
The aim of this study was to examine whether avian $\beta$-defensin proteins (av $\beta D$ s) exist in the oviduct, and whether those in the uterus are secreted to the eggshell membrane and eggshell. The oviducts of White Leghorn hens at different times of egg formation, eggshell membrane, and eggshell were used. The presence of immunoreactive (ir) av $\beta D-3,-11$, and -12 was examined by immunohistochemistry and western blot. Two or three types of av $\beta$ Ds were identified in the mucosal surface epithelial cells in each oviductal segment.

The density of ir-av $\beta D-3$ and -12 in the uterus was decreased after the egg entered this segment. Western blot analysis confirmed the presence of ir-av $\beta D-3,-11$, and -12 in the uterus. In the eggshell membrane, only ir-av $\beta D-3$ was detected on the surface of fibers at the outer layer of the membrane. The ir-av $\beta D-3,-11$, and -12 were identified in the eggshell matrix by western blot. These results suggest that the surface epithelial cells are the major sites where av $\beta$ Ds proteins exist, and the av $\beta$ Ds secreted by the uterus cells are likely to be incorporated in the eggshell membrane and eggshell. These av $\beta D$ s may play roles in the innate host defense of the oviduct and egg surface. Reproduction (2009) 138 971-978
\end{abstract}

\section{Introduction}

The hen oviduct consists of five anatomically and functionally distinct segments, namely the infundibulum, magnum, isthmus, uterus, and vagina (Palmer \& Guillette 1988). During the passage of the egg through the oviduct, the claza is secreted on the surface of the ovum in the infundibulum, whereas albumen, eggshell membrane, and eggshell components are secreted in the magnum, isthmus, and uterus respectively. The completely developed egg is oviposited through the vagina and cloaca (Gilbert 1979).

The hen oviduct may be infected by various pathogenic microorganisms such as Salmonella enteritidis (Barnhart et al. 1993) and Mycoplasma meleagridis (Yamamoto \& Herrad 1966), which may cause the functional disorder of the oviduct and contamination of eggs. The immune function of the oviduct is essential to protect the oviductal tissues from infection as well as for production of hygienic eggs.

Defensins are very common cationic antimicrobial peptides among vertebrates, which play significant roles in innate immunity, and are characterized by the presence of conserved cystine-rich defensin motifs. Based on the spacing pattern of cysteines, they are divided into $\alpha, \beta$, and $\theta$ subgroups (Haryadi \& Pak 2004, Xiao et al. 2004). The defensins in birds belong to $\beta$-defensins group (avian $\beta$-defensins: av $\beta D$ s) and are active against Gram-positive and Gram-negative bacteria, protozoans, as well as some fungi and enveloped viruses (Sugiarto \& Yu 2004, Xiao et al. 2004, van Dijk et al. 2008). In addition, they may have a chemotactic function because they can attract T-cells, monocytes, and immature dendritic cells while having toxic effects on a wide range of normal and malignant cells including those resistant to tumor necrosis factor in mammals (Bulet et al. 2004).

Fourteen types of av $\beta D$ genes have been identified, and at least 11 of these are expressed in the hen oviduct (Xiao et al. 2004, Yoshimura et al. 2006, Abdel Mageed et al. 2008). Ohashi et al. (2005) showed the mRNA expression of $a v \beta D-1,-2$, and -3 in the surface epithelium of the vagina using in situ hybridization. However, the presence of $\operatorname{av} \beta D$ proteins in the hen oviduct remains unknown.

If the $\operatorname{av} \beta D$ proteins are synthesized, they may play roles in the local host defense in the oviduct. Furthermore, if they are secreted to the egg contents during the egg formation, they may participate in the defense of eggs against microorganisms. One of the most important structures of eggs for defense against foreign agents is the eggshell and eggshell membrane that are reported to contain antimicrobial substances (Ahlborn et al. 2006, Wellman-Labadie et al. 2008). It is hypothesized that those antimicrobial substances are synthesized in the uterus and secreted to be incorporated in the eggshell membrane and eggshell during shell formation. Thus, the aim of this study was to determine 
the localization of these av $\beta$ Ds in the oviduct of laying hens, and the possibility that av $\beta D$ proteins synthesized in the uterus are secreted to the eggshell membrane as well as eggshell. The specific questions were: 1 ) which cells in the oviduct contain av $\beta D$ proteins, 2) whether the density of av $\beta D$ proteins in the uterus is changed during shell formation, and 3) whether eggshell membrane and eggshell contain av $\beta \mathrm{D}$ proteins.

We have reported that the expression of five types of av $\beta D$ s was significantly increased in response to i.v. injection with lipopolysaccharide (LPS), suggesting that synthesis of these av $\beta D$ s responds to bacterial components (Abdel Mageed et al. 2008). Among them, we selected av $\beta \mathrm{D}-3,-11$, and -12 to identify the molecules because they were the three most sensitive av $\beta$ Ds that responded to LPS.

\section{Results \\ Immunolocalization of av $\beta D-3,-11$, and -12 in the oviduct}

Immunoreaction products of av $\beta \mathrm{D}-3$ were found in the supranuclear cytoplasm of basal cells of the surface epithelium in the cephalic region of the magnum, isthmus, uterus, and vagina, whereas the density of the positive cells was highest in the uterus (Fig. 1B and D-F). On the other hand, the basal cells of the caudal region of the magnum showed a weak staining (Fig. 1C). The immunoreaction products were also found in the tubular gland cells in the magnum (cephalic and caudal regions) and isthmus (Fig. 1B-D). No cells of the infundibulum showed immunolabeling for av $\beta D$-3 (Fig. 1A).

Figure 2 shows the localization of the immunoreaction products for av $\beta D-11$. Fine granules of immunoreaction products were identified in the basal cells of the surface epithelium of the infundibulum (Fig. 2A). In the cephalic region of magnum, only the apical region of the surface epithelial cells showed a weak positive reaction (Fig. 2B). The upper cytoplasm of the surface epithelium of the caudal region of the magnum showed strong immunostaining (Fig. 2C). In the isthmus, the apical or entire cytoplasm of basal cells was densely immunolabeled (Fig. 2D). The cytoplasm of the basal cells of the surface epithelium was densely immunolabeled in the uterus (Fig. 2E), whereas the basal cells of surface epithelium of the vagina contained fine immunoreactive (ir) granules (Fig. 2F).

The immunolabeling for av $\beta \mathrm{D}-12$ was observed in the cytoplasm of basal cells in the surface epithelium of the infundibulum, caudal region of the magnum, uterus, and vagina (Fig. 3). Those immunoreaction products showed a fine granule-like appearance. The immunoreaction products were not identified in the cephalic magnum and isthmus (data not shown).

Control sections that were stained using normal rabbit IgG did not show any staining in all tissues (Fig. 4).
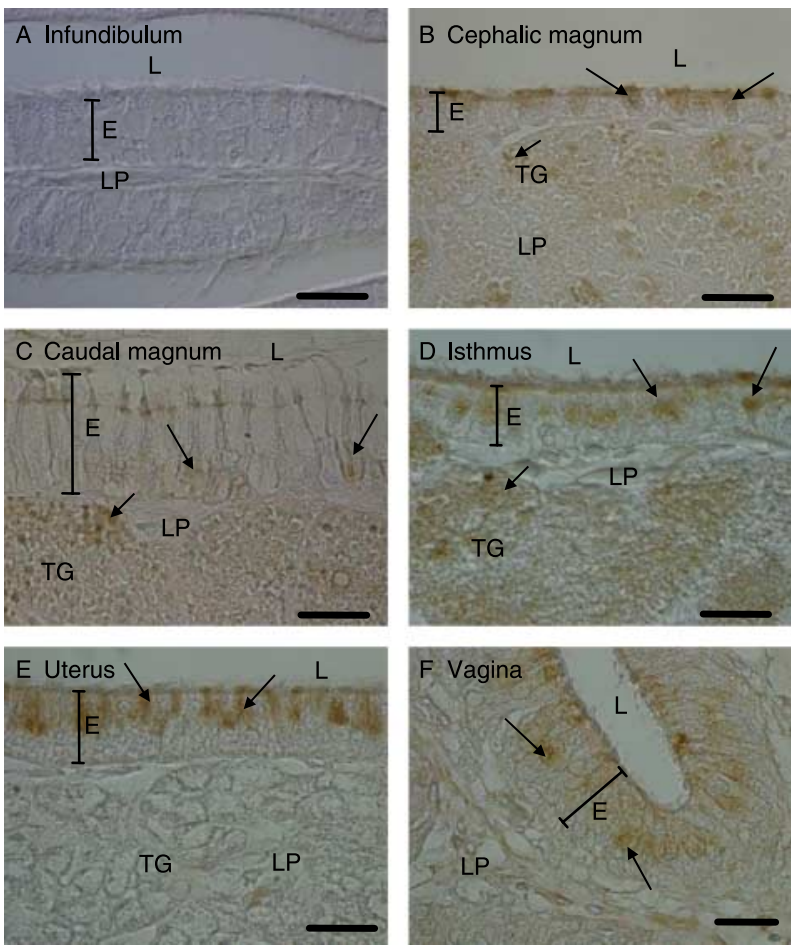

Figure 1 Sections of the oviduct of a laying hen just after oviposition immunostained for av $\beta D$-3; (A) infundibulum, (B) cephalic region of magnum, (C) caudal region of magnum, (D) isthmus, (E) uterus, and (F) vagina. The upper region of the cytoplasm of basal cells in the surface epithelium of the cephalic region of magnum, isthmus, uterus, and vagina and the lower cytoplasm of the caudal region of the magnum contain immunoreaction products (long arrows). The tubular gland cells of the magnum (cephalic and caudal regions) and isthmus are weakly stained (short arrows). L, lumen; E, surface epithelium; LP, lamina propria; TG, tubular glands. Scale bars, $20 \mu \mathrm{m}$.

Table 1 summarizes the results of immunostaining for av $\beta$ Ds in the oviductal surface epithelium. Each oviductal segment expressed immunolabeling for two or three types of av $\beta$ Ds.

\section{Western blot of av $\beta D-3,-11$, and -12 in the uterus}

Western blot analysis for av $\beta \mathrm{D}-3,-11$, and -12 in the uterus mucosal tissue showed a single band of immunoreaction products at 18, 19, and $34 \mathrm{kDa}$ respectively. No specific bands were observed in the control staining using preabsorbed antibodies or normal rabbit IgG (Fig. 5A-C).

\section{Changes in the density of av $\beta D-3,-11$, and -12 in the uterus during eggshell formation}

The changes in the density of the immunoreaction products of the three av $\beta \mathrm{Ds}$ in the uterus during eggshell formation are shown in Fig. 6 . The density of the immunoreaction products of av $\beta \mathrm{D}-3$ and -12 in the surface epithelium was decreased after the egg entered the uterus, and those of $10 \mathrm{~h}$ group was significantly 

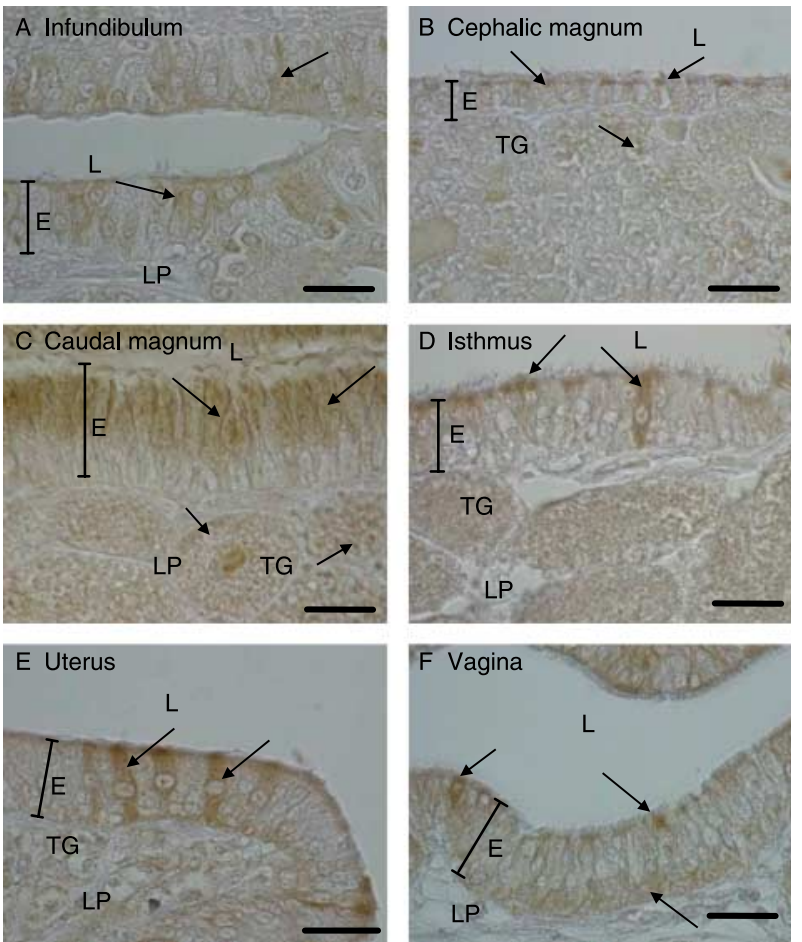

Figure 2 Sections of the oviduct of a laying hen just after oviposition immunostained for av $\beta D-11$; (A) infundibulum, (B) cephalic region of magnum, (C) caudal region of magnum, (D) isthmus, (E) uterus, and (F) vagina. Some of the surface epithelial cells of each segments shows immunolabeling for av $\beta \mathrm{D}-11$ in the whole cytoplasm except for the cephalic region of the magnum, where the immunoreaction products are located at the apical region of the cytoplasm. Arrows show immunoreaction products. See Fig. 1 for other abbreviations. Scale bars, $20 \mu \mathrm{m}$.

smaller than $0 \mathrm{~h}$ group (Fig. $6 \mathrm{~A}$ and C). In contrast, the density of av $\beta \mathrm{D}-11$ immunoreaction products did not show significant difference among 0,6 , and $10 \mathrm{~h}$ groups (Fig. 6B).

\section{Identification of av $\beta D$ s in the eggshell membrane and eggshell}

In the eggshell membrane, immunolabeling of av $\beta \mathrm{D}-3$ was detected on the surface of fibers in the outer layer of the membrane (Fig. 7), whereas no immunolabeling was detected in case of av $\beta \mathrm{D}-11$ and -12 (data not shown).

Figures 8 and 9 show the results of western blot to confirm the presence of av $\beta$ D proteins in the extramineral and intramineral extracts of the eggshell matrix proteins respectively. Specific bands were obtained at 23 and $25 \mathrm{kDa}$ for av $\beta \mathrm{D}-3,8 \mathrm{kDa}$ for av $\beta \mathrm{D}-11$, and $34 \mathrm{kDa}$ for av $\beta D-12$ in both extramineral and intramineral extracts.

\section{Discussion}

We are reporting that ir-av $\beta$ Ds were localized in hen oviduct and were identified in the eggshell membrane and eggshell. Significant findings were: 1) the surface epithelial cells of all oviductal segments contained ir-av $\beta D-3,-11$, and/or $-12,2)$ the density of ir-av $\beta D-3$ and -12 in the uterus was significantly decreased in association with entering of the egg into this segment, and 3) eggshell membrane and eggshell contained ir-av $\beta \mathrm{D}-3,-11$, and -12 . Western blot analysis using proteins isolated from the uterus mucosa showed a single band for av $\beta \mathrm{D}-3,-11$, and -12 by corresponding antibodies, but not by preabsorbed antibodies or normal rabbit IgG. These results suggest that the antibodies specifically recognized the corresponding av $\beta$ Ds.

The immunoreaction products of av $\beta D-3,-11$, and -12 were located in the basal cells of surface epithelium of all segments, and additionally those of av $\beta D-3$ were in the tubular gland cells of the magnum and the isthmus. We have identified the mRNA expression of av $\beta D-1$ to -3 in the surface epithelium of the hen vagina (Ohashi et al. 2005). The current results tend to confirm that the surface epithelium is the major site where av $\beta$ Ds are synthesized in hen oviduct. Quayle et al. (1998), who examined gene expression and immunolocalization of human defensin-5 (HD-5 now known as DEFA5) in human female reproductive tract, localized the ir-DEFA5 in the columnar cells of the surface epithelium of fallopian tubes, endometrium, and endocervix. It is likely a common feature among mammals and birds that the surface epithelial cells of female reproductive tract express $\beta$-defensin proteins.

A variety of microorganisms exist in the cloaca and may ascend the oviduct through the vagina in hens. The hen reproductive tract is the site of infectious Salmonella organisms (Chappell et al. 2009), which may invade the surface epithelium or subepithelial tissues (Takata et al. 2003). We reported that mRNA of 11 types of av $\beta D s$ including $a v \beta D-3,-11$, and -12 was expressed in the


Figure 3 Sections of the oviduct of a laying hen just after oviposition immunostained for av $\beta \mathrm{D}-12$; (A) infundibulum, (B) caudal region of magnum, $(C)$ uterus, and (D) vagina. The upper region of the cytoplasm of basal cells in the surface epithelium contains immunoreaction products (arrows). See Fig. 1 for other abbreviations. Scale bars, $20 \mu \mathrm{m}$. 

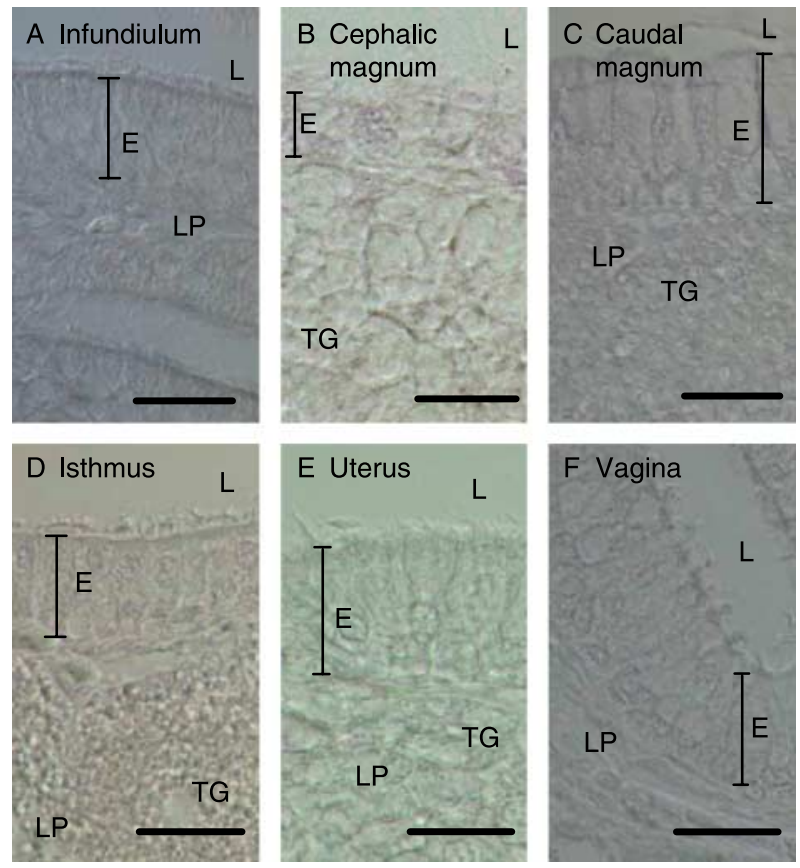

Figure 4 Sections of the oviduct of laying hens just after oviposition stained with normal rabbit IgG (control staining); (A) infundibulum, (B) cephalic region of magnum, (C) caudal region of magnum, (D) isthmus, (E) uterus, and (F) vagina. No staining is observed. See Fig. 1 for other abbreviations. Scale bars, $20 \mu \mathrm{m}$.

mucosal tissue throughout the oviduct (Abdel Mageed et al. 2008). The ir-av $\beta D-3,-11$, and -12 observed in this study confirmed that those av $\beta \mathrm{Ds}$ were synthesized in the oviduct. However, the protein amount of synthesized av $\beta D-3$ in the infundibulum and av $\beta D-12$ in the magnum and isthmus is likely negligible in healthy hens because their immunoreaction products were not identified. Previous reports suggested that, in the chicken oviduct, various antimicrobial peptides or proteins such as peroxidase, lysozyme, ovotransferrin, $\beta$ - $N$-acetylglucosaminidase, and histone proteins were synthesized (Ahlborn et al. 2006, Silphaduang et al. 2006, Yoshimura et al. 2006). The av $\beta$ Ds synthesized in the oviduct may participate in the formation of the innate immune system in this organ in combination with other antimicrobial peptides and proteins. Toll-like receptors (TLRs) recognize pathogen-associated molecular patterns. We have identified the expression of six types of TLRs including TLR4 in the hen oviduct
(Ozoe et al. 2009). TLR4 recognizes LPS of Gram-negative bacteria such as Salmonella organisms. We also found that i.v. injection of hens with LPS caused an increase in the mRNA expression of av $\beta D-3,-11$, and -12 (Abdel Mageed et al. 2008). It is assumed that synthesis of av $\beta D s$ is enhanced in response to recognition of microorganisms by TLRs.

The density of the ir-av $\beta \mathrm{D}-3$ and -12 in the surface epithelium of the uterus was significantly decreased when the egg entered this part of the oviduct. This result suggests the possibility that they were secreted from the epithelial cells. During the egg formation, uterus fluid containing organic substances and salts is secreted from the uterus mucosa, and the egg surrounded by eggshell membrane takes up this fluid before calcification (Johnson 1999). The av $\beta$ Ds secreted by the uterus cells may be contained in the fluid. The eggshell membrane consisted of a fibrous network. The surface of the fibers was immunopositive for av $\beta \mathrm{D}-3$, although the body of the fibers was not positive for av $\beta D-3,-11$, and -12 immunoreaction. It is suggested that av $\beta \mathrm{D}-3$ secreted by uterus surface epithelium into the uterus fluid attached to the surface of eggshell membrane fibers at early phase when the egg takes up the uterus fluid. Western blot examination of the eggshell indicated that the eggshell also contained av $\beta D-3,-11$, and -12 proteins. Those av $\beta$ Ds secreted from the uterus mucosa into the uterus fluid are likely to be incorporated in the shell matrix. Although the changes in the density of av $\beta D-11$ in the uterus surface epithelium were not significant, it is possible that av $\beta \mathrm{D}-11$ could be involved in the secretion because eggshell contained that protein.

Western blot analysis of the eggshell showed two different-sized bands ( 23 and $25 \mathrm{kDa}$ ) that were higher than uterus av $\beta \mathrm{D}-3(18 \mathrm{kDa})$. The two different forms of av $\beta \mathrm{D}-3$ might be appeared by binding of some residues to the tissue form of av $\beta D$ - 3 during the process of secretion. Yudin et al. (2005) reported that carbohydrate residues were added to the defensin molecules to enhance their activity. On the other hand, av $\beta D-11$ in the eggshell showed a band smaller than the tissue form, indicating that some splicing might be caused in the tissue form of av $\beta D-11$ during secretion. In contrast, the molecular size of av $\beta D-12$ was similar to the tissue form, indicating that neither splicing nor adding of residues may occur in the tissue form.

Table 1 Summary of the distribution of immunoreactive av $\beta D-3,-11$, and -12 in the surface epithelium of different segments of the hen oviduct.

\begin{tabular}{|c|c|c|c|c|c|c|}
\hline \multirow[b]{2}{*}{ Types of av $\beta D s$} & \multirow[b]{2}{*}{ Infundibulum } & \multicolumn{2}{|c|}{ Magnum } & \multirow[b]{2}{*}{ Isthmus } & \multirow[b]{2}{*}{ Uterus } & \multirow[b]{2}{*}{ Vagina } \\
\hline & & Cephalic & Caudal & & & \\
\hline av $\beta D-3$ & ND & + & + & + & + & + \\
\hline av $\beta D-11$ & + & + & + & + & + & + \\
\hline av $\beta D-12$ & + & ND & + & ND & + & + \\
\hline
\end{tabular}

+ , immunoreaction products were found. ND, no products were detected. 

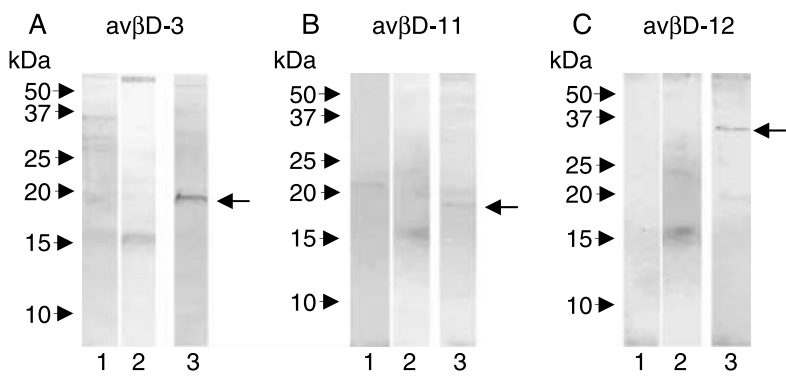

Figure 5 Western blotting for av $\beta D-3(A),-11(B)$, and -12 (C) proteins from the mucosal tissue of the uterus just after oviposition. Lane 3 was immunostained by av $\beta \mathrm{D}$ antibodies, whereas lanes 1 and 2 were stained using preabsorbed antibody and normal rabbit IgG in place of $\mathrm{av} \beta \mathrm{D}$ antibodies respectively. Arrows show the specific bands for immunoreactive av $\beta D$ s. Specific bands were identified at 18, 19, and $34 \mathrm{kDa}$ for av $\beta \mathrm{D}-3,-11$, and -12 respectively.

Previous studies showed that the components of the eggshell membrane and eggshell exhibit antimicrobial activities (Poland \& Sheldon 2001, Mine et al. 2003). More recently, antimicrobial proteins including $\beta-N-$ acetylglucosaminidase, lysozyme, and ovotransferrin were identified in the eggshell membrane (Ahlborn et al. 2006). Properties of antimicrobial proteins such as L-type lysozyme, ovotransferrin, ovocalyxin-36 and c-type lectin-like proteins are also reported in the eggshell matrix (Gautron et al. 2006, Wellman-Labadie et al. 2008). The av $\beta$ Ds in the eggshell membrane and eggshell matrix may form the defense system of the egg surface in combination with other antimicrobial proteins.

In conclusion, we suggest that the surface epithelial cells are the site where av $\beta D-3,-11$, and -12 proteins are present in the oviduct, and the av $\beta$ Ds in the uterus are likely to be secreted and incorporated in the eggshell membrane and eggshell during shell formation. These av $\beta$ Ds may play roles in the host innate immune system in the oviduct and defense of the eggshell membrane and eggshell.

\section{Materials and Methods}

\section{Experimental birds}

White Leghorn hens of $~ 400$-day-old age and laying five or more eggs in a sequence were used. They were kept in individual cages and provided with feed and water ad libitum under a light regimen of $14 \mathrm{~h}$ light: $10 \mathrm{~h}$ darkness. The birds were divided into three groups and oviductal samples were collected at different times of the ovulatory cycle; $0 \mathrm{~h}$ group (just after oviposition; corresponding to the time before the entrance of ovum into the oviduct, namely just before ovulation), $6 \mathrm{~h}$ group $(6 \mathrm{~h}$ after oviposition; just after the entrance of egg into the uterus), and $10 \mathrm{~h}$ group (10 $\mathrm{h}$ after oviposition; $\sim 4 \mathrm{~h}$ after the entrance of eggs in the uterus). They were killed under anesthesia with sodium pentobarbital (Abbott Laboratories) before collecting the oviducts. Handling of birds was done in accordance with the regulations of Hiroshima University for animal experiments.

\section{Antibodies to Ds}

Rabbit anti-av $\beta D-3$ and anti-av $\beta D-12$ antiserum were produced in rabbits using synthetic peptides and have been used in the previous studies (Yoshimura et al. 2007, Subedi et al. 2008). Antiserum to av $\beta \mathrm{D}-11$ was prepared by immunization of rabbits with KLH-conjugated synthetic peptide. The sequences of the synthetic peptides were as follows: av $\beta D-3$, RFPHI AIGKC ATF; av $\beta D-11$, CPKPF AAFGT; and av $\beta D-12$, GPDSC NHDRG LCRVG NCNPG EYLAK YCFEP VILCC KPLSP TPTKT. The sequences of those peptides corresponded to their specific sequence (Xiao et al. 2004). The IgGs in those antiserum and normal rabbit serum (for control staining) were purified using HiTrap affinity Protein G


Figure 6 Changes in the density of the immunoreactive av $\beta D-3(A),-11$ (B), and -12 (C) in the surface epithelium of the uterus during the egg formation (ratio of immunopositive area). The temporal status of the ovum of groups 0,6 , and $10 \mathrm{~h}$ after oviposition corresponds to just before ovulation, just after entering the uterus, and $4 \mathrm{~h}$ after entering the uterus respectively. Values are mean \pm S.E.M. $(n=4)$. Values with different letters are significantly different $(P<0.05)$. 

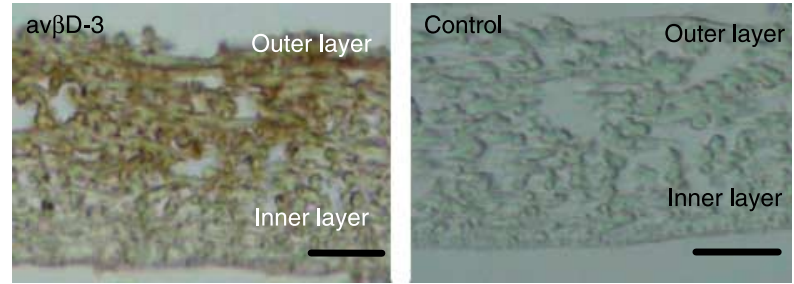

Figure 7 Micrograph of the eggshell membrane immunostained for av $\beta D-3$. Note that the surface of the fibers at the outer layer is densely stained (arrows). Control stained with normal rabbit IgG shows no staining. Scale bars, $20 \mu \mathrm{m}$.

HP column (GE Healthcare Bio-Sciences AB, Björkgatan 30, Uppsala, Sweden). Preabsorbed antibodies were prepared by incubating the antibody with excess of its corresponding peptide overnight at $4{ }^{\circ} \mathrm{C}$.

\section{Immunohistochemistry for av $\beta D$ s in the oviduct and eggshell membrane}

\section{Immunostaining}

The oviductal tissues of $0 \mathrm{~h}$ group were examined to identify the general localization of av $\beta$ Ds in the entire oviduct. Changes in the localization of av $\beta D$ s in the uterus were examined in 0 , 6 , and $10 \mathrm{~h}$ groups ( $n=4$ each). Tissues of the tubular region of the infundibulum, magnum (cephalic and caudal regions), isthmus, uterus, and vagina were fixed in freshly prepared $4 \%$ $(\mathrm{w} / \mathrm{v})$ paraformaldehyde in PBS and processed for paraffin sections $(4 \mu \mathrm{m})$. The eggshell membranes were striped from the eggshell of fresh eggs $(n=4)$, and processed for paraffin sections in a same manner.

Sections were deparaffinized and rehydrated before they were autoclaved for $10 \mathrm{~min}$ in $0.1 \mathrm{~mol} / /$ citric acid $(\mathrm{pH} \mathrm{6.8)} \mathrm{for}$ antigen activation. Sections were then cooled and washed in PBS $(3 \times 5 \mathrm{~min})$. The immunohistochemical staining was performed using anti-av $\beta D-3,-11$, and -12 antibodies, and Vectastain ABC kit (Vector Lab., Inc., Burlingame, CA, USA) according to the manufacturer's instructions. Briefly, sections were incubated with a blocking solution (normal goat serum, $15 \mu \mathrm{l} / \mathrm{ml}$ in PBS) for $1 \mathrm{~h}$ in a humid chamber at room
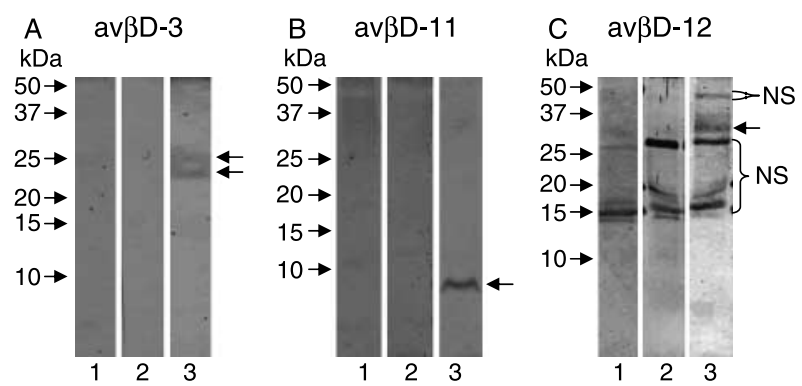

Figure 8 Western blotting for av $\beta \mathrm{D}-3(\mathrm{~A}),-11$ (B), and -12 (C) proteins from the extramineral extract of eggshell. Specific bands are identified at 23 and $25 \mathrm{kDa}$ for av $\beta \mathrm{D}-3,8 \mathrm{kDa}$ for av $\beta \mathrm{D}-11$, and $34 \mathrm{kDa}$ for av $\beta \mathrm{D}-12$ (arrows). Lanes 3 of A-C were immunostained by specific antibodies, whereas lanes 1 and 2 were incubated with preabsorbed antibodies or normal rabbit IgG (control staining). NS, nonspecific bands that were found in control staining.

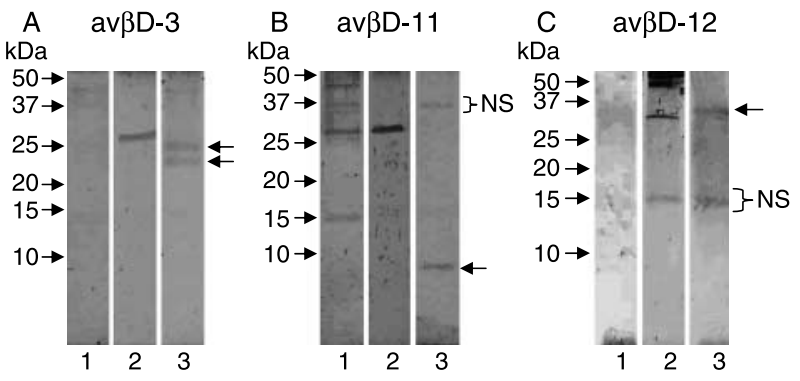

Figure 9 Western blotting for $\operatorname{av} \beta \mathrm{D}-3(\mathrm{~A}),-11(\mathrm{~B})$, and $-12(\mathrm{C})$ proteins from the intramineral extract of eggshell. Specific bands are identified at 23 and $25 \mathrm{kDa}$ for av $\beta \mathrm{D}-3,8 \mathrm{kDa}$ for av $\beta \mathrm{D}-11$, and $34 \mathrm{kDa}$ for av $\beta \mathrm{D}-12$. For more explanation, refer to Fig. 8 .

temperature. They were then incubated for $4 \mathrm{~h}$ at room temperature with one of the antibodies to av $\beta \mathrm{Ds}$ or normal rabbit IgG (for control staining) diluted at a concentration of $20 \mu \mathrm{g} / \mathrm{ml}$ using the blocking solution. Sections were then washed in PBS ( $5 \mathrm{~min} \times 3$ ) and incubated with biotinylated goat anti-rabbit IgG and avidin-biotin peroxidase complex for $1 \mathrm{~h}$ each. After washing in PBS ( 5 min $\times 3)$, the immunoreaction products were visualized using $0.02 \%$ (w/v) 3, $3^{\prime}$-diaminobenzidine tetrahydrochloride and $0.005 \%(\mathrm{v} / \mathrm{v})$ hydrogen peroxide in $0.05 \mathrm{~mol} / \mathrm{l}$ Tris- $\mathrm{HCl}, \mathrm{pH}$ 7.6. Sections were then counterstained with hematoxylin, dehydrated in ascending grades of ethanol, cleared, and covered.

Image analysis

Sections of the uterus immunostained for av $\beta D$ s were examined under a light microscope with image analysis software (Image-Pro Plus, Media Cybernetics, Silver Springs, MD, USA). The immunopositive area and total measured area in the surface epithelium were analyzed, and the ratio of positive area to the total measured area was obtained. Three different regions in one tissue were analyzed and the mean value was used for the value of one tissue.

\section{SDS-PAGE and western blotting for $\mathrm{Ds}$ in the uterus and eggshell}

Sample preparation

Uterus mucosa protein. Uterus mucosal tissues of healthy birds of $0 \mathrm{~h}$ group were collected and homogenized in five times volume of homogenization buffer consisting of $0.02 \mathrm{~mol} / \mathrm{l}$ Tris- $\mathrm{HCl}, \mathrm{pH} 7.4,0.15 \mathrm{~mol} / \mathrm{l} \mathrm{NaCl}, 0.005 \mathrm{~mol} / \mathrm{l}$ EDTA, 1\% (v/v) Triton X-100, 10\% (w/v) glycerol, 0.1\% (w/v) SDS, and $0.001 \mathrm{~mol} / \mathrm{l}$ phenylmethylsulfonylfluoride (PMSF). The samples were centrifuged at $12000 \mathrm{~g}$ for $20 \mathrm{~min}$. The supernatant was collected, and the proteins were precipitated by $40 \%(\mathrm{w} / \mathrm{v})$ ammonium sulfate and centrifuged at $9000 \mathrm{~g}$ for $20 \mathrm{~min}$. The protein precipitates were dissolved in water at a concentration of $1.5 \mu \mathrm{g} / \mu \mathrm{l}$ and used as the protein samples. The protein concentration was measured using protein assay reagent (Bio-Rad Lab) as described by the manufacturer. 
Eggshell matrix protein. The proteins in the eggshell matrix were extracted as described by Hincke et al. (2000) and Gautron et al. (2001). Briefly, the eggshells without eggshell membrane were collected from fresh eggs $(n=4$; ten eggs were pooled for one sample). They were rinsed in saline containing $0.001 \mathrm{~mol} / \mathrm{I}$ PMSF. The eggshells were then air-dried and ground into fine powder. The powder (25 g) was continuously stirred at room temperature in $100 \mathrm{ml}$ of $4 \mathrm{~mol} / \mathrm{l}$ guanidine$\mathrm{HCl}(\mathrm{pH} .7 .4)$ for 4 days at $4{ }^{\circ} \mathrm{C}$. The mixture was then centrifuged at $12000 \mathrm{~g}$ to separate the supernatant (extramineral extracts) and precipitate. The precipitate fractions were further demineralized with $0.5 \mathrm{~mol} / \mathrm{l}$ EDTA, $0.05 \mathrm{~mol} / \mathrm{l}$ Tris- $\mathrm{HCl}(\mathrm{pH} \mathrm{7.4)}$ for $1 \mathrm{~h}$, and mixed with $200 \mathrm{ml}$ of $4 \mathrm{~mol} / \mathrm{l}$ guanidine- $\mathrm{HCl}(\mathrm{pH} 7.4)$ for 1 day with continuous shaking at $4{ }^{\circ} \mathrm{C}$. They were then centrifuged at $12000 \mathrm{~g}$, and the supernatant was collected as intramineral extracts.

The extramineral and intramineral extracts were filtered through $0.45 \mu \mathrm{m}$ cellulose acetate filter (Toyo Roshi Kaisha Ltd, Tokyo, Japan), followed by isolation of proteins using Sep-Pak cartridge (Waters Corp., Milford, MA, USA). The eluted fractions were freeze-dried, and the protein concentration was adjusted to $1 \mathrm{mg} / \mathrm{ml}$ using PBS.

\section{Tricine-SDS-PAGE}

The samples were separated by Tricine-SDS-PAGE (16\% (w/v) polyacrylamide separating gel and $4 \%(\mathrm{w} / \mathrm{v})$ stacking gel) as described by Schägger (2006) with minor modifications. Briefly, samples were dissolved in sample buffer composed of $30 \%(\mathrm{v} / \mathrm{v})$ glycerol, 5\% (v/v) mercaptoethanol, 4\% (w/v) SDS, $0.15 \mathrm{~mol} / \mathrm{l}$ Tris- $\mathrm{HCl}, \mathrm{pH} 7.0$, and $0.06 \%(\mathrm{w} / \mathrm{v})$ bromophenol blue, and boiled for $10 \mathrm{~min}$. An aliquot of each sample $(10 \mu \mathrm{g}$ protein) was loaded onto gels and run at $80 \mathrm{~V}$ in the stacking gel and at $150 \mathrm{~V}$ in the separating gel.

\section{Western blotting}

After SDS-PAGE, the proteins in the gel were electrophoretically transferred onto the nitrocellulose membrane (PALL Gelman Laboratory, Ann Arbor, MI, USA) at $350 \mathrm{~mA}$ for $60 \mathrm{~min}$. The membrane was washed with western buffer (0.02 M Tris- $\mathrm{HCl}, \mathrm{pH} 7.4,0.15 \mathrm{~mol} / \mathrm{l} \mathrm{NaCl}, 0.5 \%$ (w/v) Tween 20 , and $0.05 \%(\mathrm{w} / \mathrm{v}) \mathrm{BSA})$ for $15 \mathrm{~min}(5 \mathrm{~min} \times 3)$ and incubated with $5 \%(\mathrm{w} / \mathrm{v})$ casein milk (Roche) solution in western buffer (for $1 \mathrm{~h}$ for uterus mucosa tissue samples; $2 \mathrm{~h}$ for eggshell samples). The membranes blotted with uterus mucosa proteins were incubated with av $\beta \mathrm{D}-3,-11$, or -12 antibodies diluted at a concentration of $10 \mu \mathrm{g} / \mathrm{ml}$ in $1 \%(\mathrm{w} / \mathrm{v})$ casein milk diluted in Can Get Signal Immunoreaction Enhancer Solution 1 for primary antibody (Toyobo Co., Ltd, Osaka, Japan) for $1 \mathrm{~h}$ at room temperature. The membranes blotted with eggshell proteins were incubated for $2 \mathrm{~h}$ with antibodies to av $\beta \mathrm{D}-3$ or $-11(10 \mu \mathrm{g} / \mathrm{ml})$ or for $4 \mathrm{~h}$ with antibody to av $\beta \mathrm{D}-12(20 \mu \mathrm{g} / \mathrm{ml})$. The membrane was then washed in western buffer for $30 \mathrm{~min}$ $(10 \mathrm{~min} \times 3)$ before incubation with alkaline phosphataseconjugated goat anti-rabbit IgG (Assay Designs, Inc., Ann Arbor, MI, USA) diluted at 1:5000 in $1 \%(\mathrm{w} / \mathrm{v})$ casein milk in Can Get Signal Immunoreaction Enhancer Solution 2 for second antibody (Toyobo Co., Ltd) for $1 \mathrm{~h}$ at room temperature.
The membrane was washed with western buffer for 30 min ( $10 \min \times 3$ times), and the immunoprecipitates on the membrane were visualized by incubating in a reaction mixture composed of $0.017 \%$ (w/v) 5-bromo-4-chloro-3-indolyl phosphate disodium salt (Sigma-Aldrich, Inc.) and $0.45 \%(\mathrm{w} / \mathrm{v})$ nitro blue tetrazolium (Nacalai Tesque, Inc., Kyoto, Japan) in substrate buffer $(0.1 \mathrm{~mol} / \mathrm{l}$ Tris- $\mathrm{HCl}(\mathrm{pH} \mathrm{9.5)}, 0.1 \mathrm{~mol} / \mathrm{l} \mathrm{NaCl}$, and $0.5 \mathrm{~mol} / / \mathrm{MgCl}_{2}$ ). The membrane was finally washed in running water to stop the reaction.

For the control staining, the first antibodies were replaced with normal rabbit IgG or preabsorbed antibodies.

\section{Statistical analysis}

The results were expressed as mean \pm S.E.M. of the ratio of immunopositive area to total measured area (av $\beta D$ s immunohistochemistry in the uterus). The significance of differences was examined using a one-way ANOVA, followed by Duncan's multiple range test. A $P$ value of $<0.05$ was considered statistically significant.

\section{Declaration of interest}

The authors declare that there is no conflict of interest that could be perceived as prejudicing the impartiality of the research reported.

\section{Funding}

This work was supported by a Grant-in-Aid for Scientific Research from Japan Society for the Promotion of Science.

\section{Acknowledgements}

We wish to thank Prof. Dr Lawrence M Liao, Graduate School of Biosphere Science, Hiroshima University for critical editing of this manuscript.

\section{References}

Abdel Mageed AM, Isobe N \& Yoshimura Y 2008 Expression of avian $\beta$ defensins in the oviduct and effects of lipopolysaccharide on their expression in the vagina of hens. Poultry Science 87 979-984.

Ahlborn GJ, Clare DA, Sheldon BW \& Kelly RW 2006 Identification of eggshell membrane proteins and purification of ovotransferrin and $\beta$-NAGase from hen egg white. Protein Journal 1 71-81.

Barnhart HM, Dreesen DW \& Burke JL 1993 Isolation of Salmonella from ovaries and oviducts from whole carcasses of spent hens. Avian Diseases 37 377-380.

Bulet P, Stocklin R \& Menn L 2004 Anti-microbial peptides: from invertebrates to vertebrates. Immunological Reviews 198 169-184.

Chappell L, Kaiser P, Barrow P, Jones MA, Johnston C \& Wigley P 2009 The immunobiology of avian systemic salmonellosis. Veterinary Immunology and Immunopathology 128 53-59.

van Dijk A, Veldhuizen EJA \& Haagsman HP 2008 Avian defensins. Veterinary Immunology and Immunopathology 124 1-18.

Gautron J, Hincke MT, Mann K, Panhe'leux M, Bain M, McKee MD, Solomon SE \& Nys Y 2001 Ovocalyxin-32, a novel chicken eggshell matrix protein. Journal of Biological Chemistry 276 39243-39252. 
Gautron J, Murayama E, Vignal A, Morisson M, McKee MD, Réhault S, Labas V, Belghazi M, Vidal ML, Nys Y et al. 2006 Cloning of ovocalyxin36, a novel chicken eggshell protein related to lipopolysaccharidebinding proteins, bactericidal permeability-increasing proteins, and Plunc family proteins. Journal of Biological Chemistry 282 5273-5286.

Gilbert AB 1979 Female genital organs. In Form and Function in Birds, vol 1, pp 237-360. Eds AS King \& J McLelland. London: Academic Press.

Haryadi S \& Pak L 2004 Avian antimicrobial peptides: the defense role of $\beta$-defensins. Biochemical and Biophysical Research Communications 323 721-727.

Hincke MT, Gautron J, Panheleux M, Garcia-Ruiz J, McKeed MD \& Nys Y 2000 Identification and localization of lysozyme as a component of eggshell membranes and eggshell matrix. Matrix Biology 19 443-453.

Johnson AL 1999 Reproduction in the female. In Avian Physiology, edn 5, pp 569-596. Ed GC Whittow. New York: Academic Press.

Mine Y, Oberle C \& Kassaify Z 2003 Eggshell matrix proteins as defense mechanism of avian eggs. Journal of Agricultural and Food Chemistry $\mathbf{5 1}$ 249-253.

Ohashi H, Subedi K, Nishibori M, Isobe N \& Yoshimura Y 2005 Expressions of antimicrobial peptide gallinacin-1,-2 and-3 mRNAs in the oviduct of laying hens. Journal of Poultry Science 42 337-345.

Ozoe A, Isobe N \& Yoshimura Y 2009 Expression of Toll-like receptors (TLRs) and TLR4 response to lipopolysaccharide in hen oviduct. Veterinary Immunology and Immunopathology 127 259-268.

Palmer BD \& Guillette L 1988 Histology and morphology of the female reproductive tract of the tortoise Gopherus polyphemus. American Journal of Anatomy 183 200-211.

Poland AL \& Sheldon BW 2001 Altering the thermal resistance of food borne bacterial pathogens with an eggshell membrane waste by-product. Journal of Food Protection 64 486-492.

Quayle AJ, Porter EM, Nussbaum AA, Wang YM, Brabec C, Yip KP \& Mok SC 1998 Gene expression, immunolocalization, and secretion of human defensin-5 in human female reproductive tract. American Journal of Pathology 152 1247-1258.

Schägger H 2006 Tricine-SDS-PAGE. Nature Protocols 1 16-22.

Silphaduang U, Hincke MT, Nys Y \& Mine Y 2006 Antimicrobial proteins in chicken reproductive system. Biochemical and Biophysical Research Communications 340 648-655.
Subedi K, Isobe N \& Yoshimura Y 2008 Changes in the localization of immunoreactive avian $\beta$-defensin-12 in ovarian follicles during follicular growth and in response to lipopolysaccharide. Journal of Poultry Science 45 210-214.

Sugiarto H \& Yu PL 2004 Avian antimicrobial peptides: the defense role of $\beta$-defensins. Biochemical and Biophysical Research Communications 323 721-727.

Takata T, Liang J, Nakano H \& Yoshimura Y 2003 Invasion of Salmonella enteritidis in the tissues of reproductive organs in laying Japanese quail: an immunocytochemical study. Poultry Science 82 1170-1173.

Wellman-Labadie O, Picman J \& Hincke MT 2008 Antimicrobial activity of cuticle and outer eggshell protein extracts from three species of domestic birds. British Poultry Science 49 133-143.

Xiao Y, Hughes AL, Ando J, Matsuda Y, Cheng JF, Skinner-Noble D \& Zhang G 2004 A genome-wide screen identifies a single $\beta$-defensin gene cluster in the chicken: implications for the origin and evolution of mammalian defensins. BMC Genomics 5 56-66.

Yamamoto R \& Herrad B 1966 Pathogenicity of Mycoplasma meleagridis for turkey and chicken embryos. Avian Diseases 10 268-272.

Yoshimura Y, Ohashi H, Subedi K, Nishibori M \& Isobe N 2006 Effects of age, egg-laying activity, and Salmonella-inoculation on the expressions of gallinacin. Journal of Reproduction and Development 52 211-218.

Yoshimura Y, Tsuchida M, Nakamura J, Saito T, Isobe N \& lijima N 2007 Preparation and application for immunocytochemistry of antibody to gallinacin-3, an antimicrobial peptide, in chicken. Journal of Poultry Science 44 433-438.

Yudin AI, Treece CA, Tollner TL, Overstreet JW \& Cherr GN 2005 The carbohydrate structure of DEFB126, the major component of the Cynomolgus macaque sperm plasma glycocalyx. Journal of Membrane Biology 209 119-129.

Received 30 April 2009

First decision 5 June 2009

Revised manuscript received 4 August 2009

Accepted 19 August 2009 